\title{
Halal Tourism, Cerfication Regulation, and Research Institute Insigh From IMT-GT Countries: A Review
}

\author{
Nurul Aziza ${ }^{1}$, M. Adhi Prasnowo ${ }^{2,}$ Khoirul Hidayat $^{3}$ \\ ${ }^{1,2}$ Universitas Maarif Hasyim Latif, ${ }^{3}$ Universitas Trunojoyo Madura \\ ${ }^{*}$ Corresponding author: \\ Email:nurul_aziza@dosen.umaha.ac.id
}

\begin{abstract}
.
This review article describes halal tourism, regulations on halal certification, and halal research institutes in the Indonesia-Malaysia- Thailand Growth Triangle (IMT-GT) to accelerate economic cooperation and integration to develop the country's economy, especially regarding the incessant halal issues. The purpose of this review article is to provide a critical evaluation of those that can identify potential research areas for further exploration in relation to the conditions of halal tourism, halal certification regulations, and halal research institutions owned by the three countries. Based on the results of the review of several articles, it is found that Malaysia is better prepared to face the halal issue because it has a halal research institute that is serious about handling halal and halal certification. Malaysia also has complete halal standards compared to Indonesia and Thailand. Reflecting on Malaysia, it does not close the opportunity for Indonesia. Thailand, as well as other ASEAN countries to do the same thing as Malaysia in facing the halal issue globally in order to be able to compete with other countries. So that for further research it is necessary to develop how to measure the level of public awareness of each country towards halal products and halal certification on products so that it can provide assurance that the product or tourism visited has been guaranteed its halalness. And it does not rule out that halal certification is required for all imported products that enter other countries.
\end{abstract}

Keywords: IMT-GT, Halal Tourism, Halal Certification Regulation, Research Institute.

\section{INTRODUCTION}

The term halal comes from the Arabic language related to Islamic religious beliefs including all types of products and services to Muslims. Halal is defined on the basis of sharia, which is an attribute of quality credentials [1]. The term halal can be said to be a brand. Halal is a clear and effective philosophy for branding, product development and marketing, beyond management science, cultural anthropology, sociology, and organizational behavior [2]. According [3] Halal tourism is emerging as a new phenomenon in the growth of the halal industry. Halal tourism appears with tourism services, worship facilities, and the provision of products that meet the needs of Muslim tourists [3]. 
Finding halal tourism refers to the provision of a tourism product and service that meets the needs of Muslim travelers to facilitate worship and dietary requirement that conform to Islamic teachings. Mohsin mentions that Halal tourism adheres to Islamic values which are in line with the development of sharia banking practices that allow Muslims to calculate according to Islamic values and sharia [4].

The availabilities of halal foods and beverages are vital for destinations that target Muslim travellers. When visiting non-Muslim tourist destinations, the awareness of Muslim tourists to look for halal drinks and food has begun to be felt. Based on Islamic law, Muslims are prohibited from eating pork or products derived from pigs, animals that die without livelihoods, butchering animals that do not comply with Islamic law, their blood and blood by products, alcohol, carnivorous animals, birds of prey [5], [6], [7].

According research article of Battour, Muslim customers are one of the fastest developing market segments and its needs cannot be ignored by destination marketers and tourism operator [6], especially from IMT-GT Countries (Indonesia- Malaysia, Thailand Growth Triangle). At the initiation of the Indonesian government, subregional cooperation took the initiative to form the Indonesia-Malaysia-Thailand Growth Triangle (IMT-GT) in 1993 aimed at accelerating social and economic transformation for underdeveloped provinces. Countries of member IMT-GT has grown in geographic scope and activities to encompass more than 81 million people. It is now composed of 14 provinces in southern Thailand, 8 states of Peninsular Malaysia, and the 10 provinces of Sumatra in Indonesia. As a developing country which has a high number of Muslim, the need for halal products must be supported also by the regulation on halal. Some developing countries have established institutions that handle halal, as well as regulations on halal tourism and many research institutes have handle it.

\section{METHODS}

This review article, also called a literature review written by collect of previously published research on a topic. It should give an overview of current thinking on the theme and, unlike an original research article, won't present new experimental results. The objective of a literature review is to provide a critical evaluation of the data available from existing studies. This review articles will can identify potential research areas to explore next, and sometimes it will draw new conclusions from the existing data.

\section{RESULT AND DISCUSSION}

\subsection{Halal Certification Regulation}

To support halal tourism, countries incorporated in IMT-GT have different legislation for halal certification. In Malaysia, professes to be the only country in the world with a halal food certification strategy supported fully by government [8], and has ambitions to be a global centre. Official involvement commenced in 1974 and a Halal Industry Development Corporation (HDC) was founded in 2006. The 
Department of Islamic Development (JAKIM) certifies food and personal care products for local and export markets while the State Islamic Department (Jabatan Agama Islam Negeri) and State Islamic Council (Majlis Agama Islam Negeri) issue certificates for domestic markets only. JAKIM also recognises certification bodies overseas and 73 from 33 countries had been approved by 2014 [9]. Halal food must meet the standard MS1500: 2009 prepared by the Department of Standardisation under the Ministry of Science, Technology and Innovation. Another standard (MS 2400) applies to the transportation of goods, warehousing and retailing and forms part of a Halal Assurance Management System (Department of Islamic Development, undated). A Malaysian Halal Directory lists 17 certified food and beverage manufacturing companies, 235 food premises where food and beverage business is conducted, 2141 consumer products, 6 slaughter houses and the food and beverage operations of 422 hotels and resorts [3]. The certification process includes a site audit and monitoring and success enables public display of a formal halal logo.

According Aminuddin in his article, halal certification in Indonesia was initially civil society movement that supported by the state, which is taken by LPPOM MUI. The main objective was to protect Muslim from haram products. However, by coming out of regulation UU number 33 year 2014 about halal product guarantee, the halal certification will be carried out by the state institution, that is Security Agency Halal Products known as BPJPH [10]. While in Thailand, halal product certification is the authority of Central Islamic Council of Thailand (CICOT) which is similar to the Indonesian Ulema Council (MUI). In Thailand, Halal product certification has much giving supports to the government economic, especially for the purpose of exporting food to the Muslim countries and also to attract Muslim tourist to visit Thailand.

\section{A. Malaysian Halal Certification System}

Malaysia is unlike in other countries whose certifications are endorsed by their respective Islamic associations [11]. At the federal level, the authority for certifying the halal products and services is the Department of Islamic Development Malaysia (JAKIM) which is under the Prime Minister Department. JAKIM handle the halal certification process for products for the domestic market and international market. JAKIM's Halal logo is among the most widely recognized and respected symbols of halal compliance in the world [11]. At the state level, the certification authorities are the State Islamic Religious Department (Jabatan Agama Islam Negeri - JAIN) and State Islamic Religious Council (Majlis Agama Islam Negeri - MAIN) who are given the authority to issue the halal certificate for domestic market. Malaysia launched the Halal Standard MS 1500:2004 Halal Food - Production, Preparation, Handling and Storage - General Guidelines in the year 2006 which prescribed practical guidelines for the food industry on the preparation and handling of halal food including nutrient supplements to serve the basic requirement for food production and food trade or business in Malaysia. Conceptual of the halal certification process in Malaysia is shown in figure 1. 


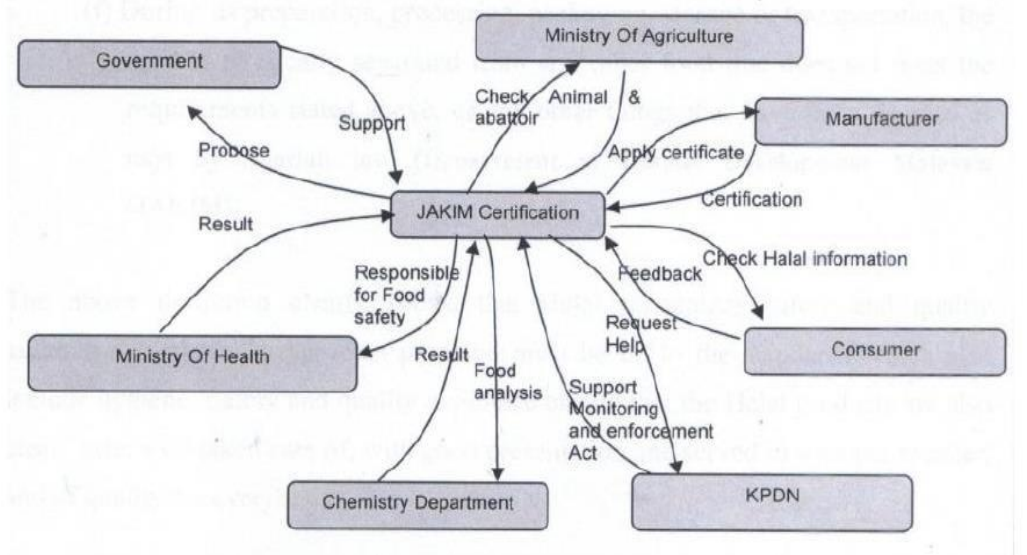

Figure 1. Conceptual of The Halal Certification Process in Malaysia Source: Ahmad Hishamuddin, 2007

B. Indonesian Halal Certification System

In Indonesia, the Indonesian Council of Ulama (Majelis Ulama Indonesia, MUI) through its LPPOM. Institutions that have responsibility protecting this Muslim initiative to give halal certificate to the product. Halal certification process in Indonesia (online) is shown in Figure 2.

Here MUI Halal Certification Procedure are:

1. Understanding halal certification requirements and following Halal Assurance System (HAS) Training.Companies must understand the halal certification requirements listed in HAS 23000. The Summary of HAS 23000 and the document can be found in website LPPOM MUI. In addition, the company must also attend HAS training which is conducted by LPPOM MUI, either in the form of regular training and online training (e-training).

2. Implementing Halal Assurance System.

Companies must implement HAS before applying and registering for halal certification process. Among them are: determining halal policies, establishing Halal Management Team, preparing HAS Manual, conducting training, preparing related HAS procedures, implementing internal audit, and reviewing management properly. To assist companies in implementing HAS, LPPOM MUI has prepared a guidance document which can be ordered.

3. Preparing Halal Certification Document.

The Company must prepare all necessary documents for halal certification process. Among them are: a list of products, a list of materials and documents of the material, a list of butchers (particularly for Slaughterhouse), matrix of products, HAS Manual, flow chart of the process, a list of production facilities addresses, evidence on halal policy dissemination, evidence on internal training and evidence on internal audit. A description of the halal certification 
documents can be viewed in Cerol user manual which can be downloaded at website of LPPOM MUI.

4. Applying and Registering for halal certification process (uploading data). Applying and Registering for halal certification is performed through online process in Cerol system, through LPPOM MUI website: www.elppommui.org. Companies must read the user manual of Cerol first to understand the halal certification procedures which can be downloaded.

5. Monitoring pre-audit and payment of contract for halal certification process.

After uploading the data of certification, the company must conduct a pre audit monitoring and payment of contract for certification process. This pre audit Monitoring is recommended to be conducted every day to find out any discrepancies in the results of pre audit. Payment of contract for certification process is performed by downloading the certification contract in Cerol, paying the cost of the contract and signing the contract, and then making payments in Cerol, and approved by the Treasurer of LPPOM MUI.: bendaharalppom@halalmui.org.

6. Performing audit.

Audits can be performed if the company is already passed in pre audit process and the contract has also been approved. Audits are conducted at all facilities related with products certified.

7. Performing post-audit monitoring.

After uploading the data certification, the company must conduct post-audit monitoring. This post-audit monitoring is recommended to be performed every day to find out any discrepancies in the results of the audit, and if there is any discrepancy, then it must be corrected properly.

8. Receiving halal certificate.

The companies can download a halal certificate in softcopy form/file in Cerol. The original halal certificate can be taken at the office of LPPOM MUI Jakarta, and it can also be sent to the address of the company. Halal certificate is valid for two (2) years.

C. Thailand Halal Certification System

Halal certification in Thailand is handled by the Central Islamic Council of Thailand (CICOT) or Syaikhul Islam of Thailand, an institution that oversees all Islamicity in Thailand. This institution is recognized by the state. Halal Standard Institute of Thailand is institutions under CICOT who handle halal certification issues. Halal certification system in Thailand can be seen in Figure 3. 


\section{HALAL CERTIFICATION SYSTEM IN THAILAND}

Islamic Organization Administration Act 1997

* ClCOT's Halal Affair Administration Regulation 2009

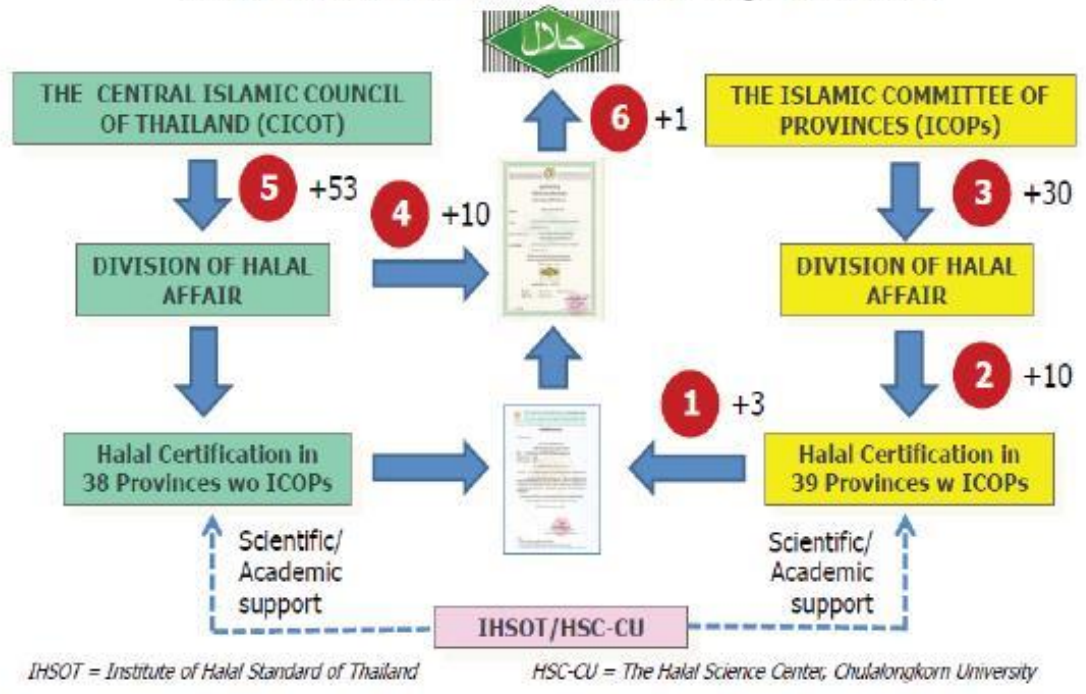

Figure 2. Halal Certification System in Thailand

Souce: Pakorn Priyakorn, Thailand Muslim Friendly Destination, presented in Islamic Center Bangkok, 8 Juni 2015

\subsection{Research Institutes}

Some research institutions in IMT-GT countries are seriously dealing with halal issues. malaysia has several colleges and research institutes about halal. In response to the rapidly growing Halal industry development in Malaysia, the International Islamic University Malaysia, with its academic and research strength and conducive Islamic environment has established a special centre that dedicated to Halal industry - "IIUM Halal Industry Research Centre"in July 2006. Prior to the birth of this centre, there were already pockets of activities related to Halal and Halal industry by academic staff from various Kulliyyahs. HIRCen, focus of halal activities at IIUM become more focus and better coordinated with the Research Management Centre becoming the monitoring body.

HIRCen was to play a crucial coordinating role for IIUM's contribution in positioning and developing Malaysia as the hub for Halal products and services as well as other interested organizations or countries, to become a key Halal products and services player. The university authority envisioned that IIUM could and should play a greater role in strengthening the research and training component of the halal industry. As such, HIRcen needs a new facelift and to broaden its scope to include long term education in Halal. INHART is a centre of excellence at the university level and is expected to be recognized as one of the Higher Institutions' Centres of Excellence (HICoE) at the national level in the near future. In UPM there is halal products research institute serves as a one-stop center or 'one-stop 
center' approach through a comprehensive, balanced and multifaceted to study all aspects of halal products in national and global levels.

In Thailand, Chulalongkorn University in 2004 by establishing The Halal Science Center, Chulalongkorn University (HSC-CU) with the support of Royal Government of Thailand. This center is one of the first research institutes in the world with a specialization in the field of halal food science. Its purpose of establishment is to assist the Thai Islamic Committee in carrying out its mission, especially in as a Halal Certification Agency. In doing its job, HSC-CU builds network and cooperation with other halal science labs in the world for the benefit of people and science. In addition, HSC-CU has been actively leading the Working Group on Halal Products and Services (HAPAS) within the framework of Indonesia-Malaysia-Thailand Growth Triangle (IMT-GT).

In Indonesia, Universitas Islam Indonesia Yogyakarta established a halal research institute called "Halalan Thoyyiban Research and Education Center" or "H-TREND" as a form of concern for the guarantee of halal products. And also University Gajah Mada has established a Halal Product Research Center (PPPH) In addition to improving the study, research and testing on halal products. Along with the development of halal product regulation, since July 1, 2011, HRG of Gadjah Mada University has been changed to PPPH. Universitas Indonesia with Special Unit Work (UKK) Center for Halal Studies University of Indonesia. Formed to resolve problems and challenges at national and global level in supporting the government by realizing the Halal Product Guarantee Act (UU $\mathrm{JPH})$.

\section{CONCLUSION}

The population of Muslims who have shown an increase in various countries, especially in the regions of Indonesia, Malaysia and Thailand has great potential in the development of halal tourism. Government support related to regulations, clarity of halal certification procedures and fulfillment of halal tourism are needed because these three Asian countries have a potential tourism market. Public awareness of halal products and tourism also needs to be developed through a sustainable and sustainable socialization program so that halal programs become part of people's lives. This research is still comparing regulations regarding halal, halal procedures. So for further research it needs to be developed on how to measure the level of public awareness of halal products and halal certification on products so as to provide assurance that the products or tours visited are guaranteed halal. And it does not rule out the possibility that halal certification is required for all imported products entering the country.

\section{ACKNOWLEDGMENTS}

With the completion of this article review, I would like to thank my doctoral promotor, Universitas Maarif Hasyim Latif, and my team who have helped a lot until the completion of all the outcomes in this research.

\section{REFERENCES}

[1] J. Jafari and N. Scott, "Muslim world and its tourisms," Ann. Tour. Res., vol. 44, pp. 119, 2014. 
[2] J. A. J. Wilson and J. Liu, "Shaping the halal into a brand?," J. Islam. Mark., vol. 1, no. 2, pp. 107-123, 2010.

[3] Z. Samori, N. Z. M. Salleh, and M. M. Khalid, "Current trends on Halal tourism: Cases on selected Asian countries," Tour. Manag. Perspect., vol. 19, pp. 131-136, 2016.

[4] A. Mohsin, N. Ramli, and B. A. Alkhulayfi, "Halal tourism: Emerging opportunities," Tour. Manag. Perspect., vol. 19, pp. 137-143, 2016.

[5] M. Battour, M. Battor, and M. A. Bhatti, "Islamic attributes of destination: Construct development and measurement validation, and their impact on tourist satisfaction," Int. J. Tour. Res., vol. 16, no. 6, pp. 556-564, 2014.

[6] M. M. Battour, M. N. Ismail, and M. Battor, "Toward a halal tourism market," Tour. Anal., vol. 15, no. 4, pp. 461-470, 2010.

[7] M. L. Stephenson, "Deciphering 'Islamic hospitality': Developments, challenges and opportunities,” Tour. Manag., vol. 40, pp. 155-164, 2014.

[8] K. G. Widagdyo, "Analisis Pasar Pariwisata Halal Indonesia," Tauhidinomics, vol. 1, no. 1, pp. 73-80, 2015.

[9] J. K. I. M. JAKIM, "Manual Procedure for Malaysia Halal Certification (Third Revision) 2014," Putrajaya, Jab. Kemajuan Islam Malaysia, 2015.

[10] M. Z. Aminuddin, "Sertifikasi Produk Halal: Studi Perbandingan Indonesia dan Thailand," SHAHIH J. Islam. Multidiscip., vol. 1, no. 1, pp. 27-39, 2016.

[11] Z. Raja Adam, "RM100m boost to make Malaysia halal hub," Bus. Times, 2006. 